\title{
Immunochromatography Detection of Ricin in Environmental and Biological Samples
}

\author{
Junhua Wu ${ }^{a}$, Yuxia Wang ${ }^{\text {a, }}$, Peiyuan Jia ${ }^{a}$, Chenyu Wang ${ }^{a}$, Yu Zhao ${ }^{a}$, Hui Peng ${ }^{b}$, Wenqing Wei ${ }^{\text {c }}$, Hua Li $^{\text {a, }}$ \\ ${ }^{\mathrm{a} B}$ Beijing Institute of Pharmacology and Toxicology, Beijing 100850, China \\ ${ }^{\mathrm{b}}$ Beijing Institute of Basic Medical Sciences, Bejing 100850, China \\ ${ }^{\mathrm{c}}$ General Hospital of Beijing Military Area Command, Beijing 100700, China \\ * Corresponding author: wangyuxia1962@hotmail.com(Yuxia Wang); amms_hli@126.com(Hua Li)
}

\begin{abstract}
Ricin has been considered as a potential agent of biological warfare or terrorist attack. This work is aimed to develop and evaluate a rapid test strip for the assay of ricin in environmental and biological samples. Two specific antibodies were used respectively as the capture antibody (Mab 4C13) coated on a nitrocellulose membrane and the tracing antibody (MAb 3D74) labeled with colloidal gold. The immunochromatography strips were tested to detect ricin in porridge, salted vegetable, water and other drinks. The detection could be finished within fifteen minutes and its sensitivity was at 10 $\mathrm{ng} / \mathrm{ml}$ of ricin in water. When no ricin control samples were tested in parallel, some kind of drinks, such as Sprite and Coca cola showed false positive bands even without toxin pollution, indicating the negative control is essential to avoid possible false positive results. The strips could give positive signals after loading human serum sample mixed with $25 \mathrm{ng} \mathrm{ml}^{-1}$ of ricin in vitro. When rats were intramuscularly treated with $100 \mathrm{ug} \mathrm{kg}^{-1}$ of ricin, the residual ricin in the serum samples could be successfully detected by the strips even at $24 \mathrm{~h}$ after intoxication. The immunochromatography test strip is a useful tool to check the possible pollution of ricin in enviromental samples such as drink and food, and even to detect the residual toxin in human serum before victim developing intoxication symptoms.
\end{abstract}

Keywords: Ricin, Antibody, Immunochromatographic Assay, Colloidal Gold, Strip Assay

Citation: H. Li, et al. Immunochromatography detection of ricin in environmental and biological samples. Nano Biomed. Eng. 2011, 3(3), 169-173. DOI: $10.5101 /$ nbe.v3i3.p169-173.

\section{Introduction}

Ricin is a heterodimeric ribosome inactivating protein which inhibits protein synthesis, consequently resulting in cell death $[7,17]$. The lethal oral dose of ricin in human has been estimated to be $1-20 \mathrm{mg} \mathrm{kg}^{-1}$ body weight [1]. In our experimental studies $5 \mu \mathrm{g} \mathrm{kg}^{-1}$ of ricin was found to be lethal in mice administered intravenously. Ricin has been considered as a potential agent of biological warfare or terrorist attack, because it can be easily isolated from castor beans and produced in sufficient quantities for weapons [13]. The well known use of ricin might have been the assassination of Georgi Markov, a Bulgarian dissident in 1978 [12, 14].

For the need of antiterrorism, various technologies have been established for ricin detection. Many of them are highly sensitive, such as biosensors based on magnetoelastic and surface Plasmon resonance [15, $19,4]$, and other methods that depend on immunopolymerase chain reaction assay [10] and microelectrode array [3]. They are useful for ricin detection in various environmental samples. Enzyme-linked immunosorbent assay (ELISA) had also been used in ricin assay with its high sensitivity and specificity $[8,11]$. Based on the mechanism of ELISA and the engineering design of colloidal gold-based immunochromatographic assay, the strip has been developed and widely used in detection of many kinds of antigens, including the detection of ricin in water and powder samples. Its sensitivity reached 10$50 \mathrm{ng} \mathrm{mL} \mathrm{m}^{-1}$ of toxin in water $[6,16]$ and be well used in the environmental example assay because of its high sensitivity and rapid operation.

In this work, a strip based colloidal gold-based immunochromatographic assay was established. It was further evaluated for its use in ricin detection in environmental and biological samples.

\section{Materials and methods}

\subsection{Material}

Ricin was obtained from the Laboratory of Toxicant Analysis, Beijing Institute of Pharmacology and 
Toxicology. Mouse ascites containing monoclonal antibodies (4C13, 3D74) were produced from Beijing Institute of Basic Medical Sciences. The antibodies were purified using protein G-sepharose 4 fast flow (Amersham). Colloidal gold particles were made in our laboratory. Nitrocellulose membrane Unisart CN 140 (Sartorius) was used as membrane and coated with capture antibody and control antibody. Male Wistar rats were supplied by the Animal Center of the Institute. They were housed in a controlled environment $(21 \pm 2$ ${ }^{\circ} \mathrm{C} ; 55 \pm 5 \%$ of humidity; $12 \mathrm{~h}$ dark/light cycle with light provided between 6 am and $6 \mathrm{pm}$ ). Food and water were given ad libitum. All the animal experiments were carried out in the Beijing Center for Drug Safety Evaluation, in accordance with a protocol approved by the Institutional Animal Care and Use Committee of the Center, which is in compliance with the guidelines of the Association for Assessment and Accreditation of Laboratory Animal Care International (AAALAC). Purified goat against mouse IgG was from KENGEN BIOTECH. CO., LTD.

\subsection{Preparation 2 of colloidal gold conjugated with antibody $3 D 74$}

Colloidal gold was prepared according to a technique of monodispersion colloidal gold $[18,5]$. Chlorauric acid was reduced by sodium citrate to produce colloidal gold particles which have a diameter about $11 \mathrm{~nm}$. Newly prepared colloidal gold $(40 \mathrm{ml})$ was conjugated with $5 \mathrm{mg}$ of monoclonal antibody 3D74 at room temperature for 20 minutes. The conjugating solution was centrifuged at $12000 \mathrm{rpm}$ and the precipitation was dissolved in $2 \mathrm{mM}$ boric buffer $\mathrm{pH} 7.2$, supplemented with 1\% BSA.

\subsection{Establishment of immunochromatograp- hic test strips}

The test strip was established following the application guide of Rapid Lateral Flow Test Strips on the Website of Millipore (http://www.millipore.com/techpublications/ tech1/tb5000en00). As the capture antibody, purified monoclonal antibody 4C13 $\left(1 \mathrm{mg} \mathrm{mL}^{-1}\right)$ dissolved in $10 \mathrm{mM}$ phosphate buffer $\mathrm{pH} 7.2$ was bound onto the membrane at the position of test line. The same amount of goat against mouse IgG was loaded at the control line. The glassfiber impregnated with colloidal gold-antibody $3 \mathrm{D} 74$ conjugate was dried at $37^{\circ} \mathrm{C}$ for $2 \mathrm{~h}$ and put under the sample pad. The strip was made by consistent laminating the membrane, sample pad, conjugating pad and absorbent pad on a support backing.

\subsection{Establishment of intoxicated animal mode}

For assessment of ricin in serum by the test strips, the rats were injected intramuscularly with $100 \mu \mathrm{g} \mathrm{kg}^{-1}$ ricin prepared in saline. Blood samples were collected at $0.5,1$, $2,4,6,8,12,16$ and 24 h post-dose, respectively, and the sera were harvested.

\subsection{Detection of ricin in various samples by test strips \\ 170 ОอดดรT}

$2 \mathrm{mM}$ boric buffer $\mathrm{pH} 7.4$, containing 5\% sucrose, $0.2 \%$ BSA and $0.04 \% \mathrm{Na}_{3} \mathrm{~N}$ was used as loading buffer. Ricin was diluted with the loading buffer to prepare the testing samples at the concentration range of $0-100 \mathrm{ng} \mathrm{mL}^{-1}$. The testing samples were assayed with the strips. Comparing with negative control, a dark red test line appeared within 15 min was considered as a positive result. The storage stability of the strips was checked after they were kept in a refrigerator at $4{ }^{\circ} \mathrm{C}$ for more than 1 year. Water, Sprite, Coca cola and the supernatant of porridge were respectively used as testing samples for the scenarios of the toxin pollution. Serum samples from rats were diluted with the loading buffer and then an aliquot of $100 \mathrm{uL}$ was dropped onto the samples pads of strips.

\section{Results}

\subsection{The detection limit of test strips}

According to the method mentioned above, the colloidal gold particles were prepared and labeled with purified antibody against ricin. The maximum absorption of colloidal gold particles with brownish red color was at $517 \mathrm{~nm}$ and $524 \mathrm{~nm}$ respectively before and after antibody labeling. The glassfiber impregnated with colloidal gold conjugate was put under the sample pad which was overlapped with the nitrocellulose membrane to establish the test strips. The labeled particles could bind with ricin molecules and then be captured by another antibody 4C13 bound at the test line on membrane to give the positive band when they flew from the sample port to the absorption pad.

Ricin in the loading buffer was assayed by test strip. The strips showed two clear red bands for samples with ricin concentrations of $10-100 \mathrm{ng} \mathrm{mL}^{-1}$, while only one control band was observed for the control samples (Fig. 1).

\subsection{The storage stability of test strips}

The test strips were sealed in aluminium foil bags and kept at $4{ }^{\circ} \mathrm{C}$ in a refrigerator for 1 to 3 years. The stability of these strips was tested using ricin standard solutions in loading buffer. The detection limit of 25, 50 and $100 \mathrm{ng}$ $\mathrm{mL}^{-1}$ were obtained for the strips reserved at $4{ }^{\circ} \mathrm{C}$ for 1,2 and 3 years, respectively (Fig. 2.).

\subsection{Detection of ricin in food and drink samples by test strips}

Poisoning through digestive tract is the one of major paths of ricin poisoning. In order to detect whether the test strips could be used to assay the ricin pollution in food and drink samples, ricin was spiked into water, rice porridge, Coca cola and Sprite. respectively and then these samples was loaded onto the strips. The ricin in water, supernatant of porridge and stir-frying tomato could be well measured with the detection limit of $25 \mathrm{ng}$ $\mathrm{mL}^{-1}$. However, Coca cola and Sprite gave false positive bands for ricin negative samples. Using loading buffer to dilute these two drink samples could eliminate the false band or decrease its intensity of staining, After the 


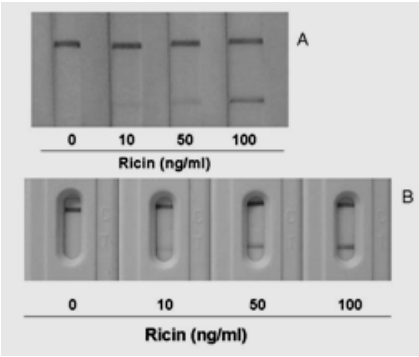

Fig. 1 Ricin detection in loading buffer by test strips. Different concentrations of ricin solutions $(100 \mathrm{uL})$ were dropped onto the sample pad of test strips directly (A) and onto the sample port of test strips with housing (B).

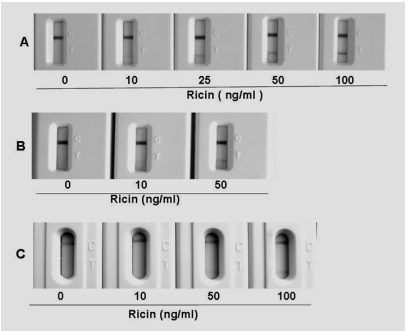

Fig. 2 Storage stability of test strips.

Test strips were kept at $4{ }^{\circ} \mathrm{C}$ for $1(\mathrm{~A}), 2(\mathrm{~B}), 3(\mathrm{C})$ years in a refrigerator and were tested with ricin spiked in loading buffer at levels over 0-100 ng $\mathrm{mL}^{-1}$.

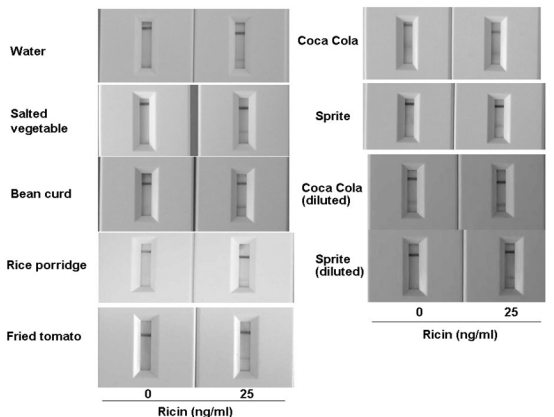

Fig. 3 Ricin detection in the food and drink samples.

Samples of food or drink were diluted with equal volume of the loading buffer spiked with $25 \mathrm{ng} \mathrm{mL}^{-1}$ of ricin. $100 \mu \mathrm{L}$ sample was dropped onto the test strip. The diluted samples were made from diluting Coca Cola and Spring with loading buffer at the ratio of 1:1 and then mixed with $25 \mathrm{ng} \mathrm{mL}^{-1}$ of ricin in loading buffer before being determined.

dilution that ricin in these two samples could be analyzed, but at the detection limit of $50 \mathrm{ng} \mathrm{mL}^{-1}$ (Fig. 3). The detection of a negative control sample (without ricin) in parallel with the real samples is essential to identify whether the positive line on the strip is from ricin or a false response caused by interferences from sample.

\subsection{Detection of ricin spiked in human serum in vitro}

The tissue damage induced by ricin could begin within several hours after intoxication, though the latency before onset of clinical signs depends on the dose and exposure route. The diagnosis for patients possibly exposed to ricin is very important for the prompt medical treatments. The detection of ricin in serum sample is convenient and acceptable. In order to determine whether the test strip could be used for detection of ricin in human serum, the

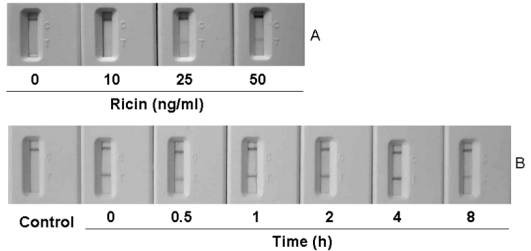

Fig. 4 Detection of ricin in human serum.

Ricin dissolved in human serum at $1-50 \mathrm{ng} \mathrm{mL}^{-1}$ was used to detect

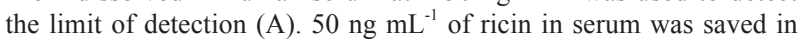
incubator at $37^{\circ} \mathrm{C}$ for $0-8$ hours and then diluted with equal volume of loading buffer before detected by test strips.

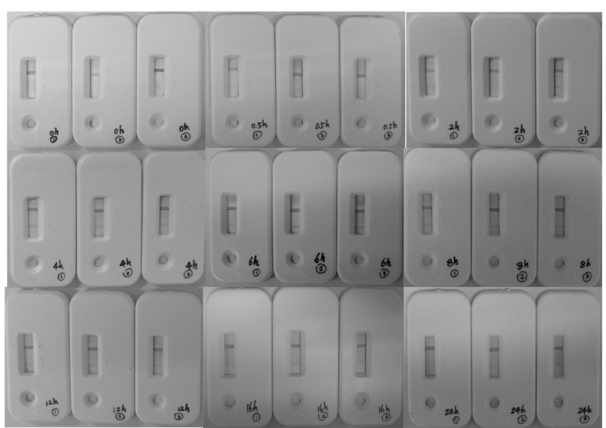

Fig. 5 Ricin detection in serum samples of rats after poisoned with a lethal dose.

Ricin was intramuscularly injected at $100 \mu \mathrm{g} \mathrm{kg}^{-1}$ to the gluteus maximus of rats. Three serum samples at different time points were collected and then diluted (1:1) with loading buffer being measured by test strips.

human serum samples was spiked with ricin in vitro and kept at $37{ }^{\circ} \mathrm{C}$ for different time periods before tested with the strips. The result indicated that ricin in human serum could be detected at the sensitivity of $25 \mathrm{ng} \mathrm{mL}^{-1}$ and the ricin was stable in serum at $37{ }^{\circ} \mathrm{C}$ for 8 hours without significantly degradation (Fig. 4).

\subsection{Detection of ricin in sera of the ricin exposed rats}

The test strip could be well used to detect the toxin inenvironmental samples. The method is rapid and sensitive. It could also capture the ricin in human serum with the the detection limit of $25 \mathrm{ng} \mathrm{mL}^{-1}$. In this study, serum samples from ricin exposed rats were also tested. The serum samples were collected after rats received a lethal ricin dose $\left(100 \mu \mathrm{g} \mathrm{kg}^{-1}\right)$ by intramuscular injection and then diluted with the loading buffer at the ratio of $1: 1$. The brownish red test lines on the strips were observed for the serum samples harvested at 1 to $24 \mathrm{~h}$ post-exposure, suggesting that the strips might be used as a field detection tool for checking the toxin in biological samples taken from exposed victims (Fig. 5).

\section{Discussion}

Various technologies have been developed for ricin detection [9]. Among them the colloidal gold-based immunochromatographic assay based strip [6, 16] was widely used for field or daily detection. It is sensitive, rapid and easy to handle, especially for detection of environmental samples. In this study a test strip was established using immunochromatographic method. Two antibodies bond with two different epitopes of 
ricin were used for colloidal gold particle labeling and capturing antibody respectively. Using this strip the ricin in boric buffer ( $\mathrm{pH}$ 7.4) was successfully assayed within 15 minutes with the detection limit of $10 \mathrm{ng} / \mathrm{ml}$ (Fig.1). After stored at $37{ }^{\circ} \mathrm{C}$ for 3 years, the strip could still give positive response at the ricin level of 50-100 $\mathrm{ng} \mathrm{mL}^{-1}$ (Fig. 2).

As previously reported, there were some contents in samples that could disturb ricin detection [2]. In this study various types of samples, including food and beverages were selected to test the possible interferences on ricin detection by strips. When spiked in water, porridge, the supernatants of bean curd and fried tomato ricin was well

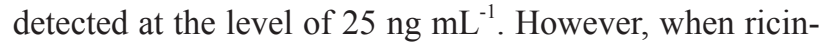
free samples of Coca Cola and Sprite were loaded, false positive bands appeared, indicating some contents in these samples could affect the immunoassay. Dilution with loading buffer would eliminate or reduce the interference (Fig. 3). The strip is able to detect ricin in these samples when the samples are appropriately diluted with loading buffer and the negative controls is assayed parallelly. Other detection method can also be used to reconfirm the result by the test strip.

So far, the immunochromatographic strips are mainly used for ricin detection in environmental samples, such as water and solid powder. No report for their use in biological samples has been seen, despite of the fact that the early detection of ricin intoxication in human is extremely important for taking necessary medical treatment. Generally, the latency of clinical symptom of ricin poisoning is several hours depending on the route of intoxication and the toxin dosage applied. A rapid identification of poisoning source and a correct diagnosis are very important for successful clinical treatments against ricin poisoning. In this study the strip was tested with serum samples from human and rat to determine whether it could be used to detect ricin in biological samples. The human serum spiked with ricin was maintained in $37{ }^{\circ} \mathrm{C}$ incubator for different time periods before loading onto the strips. Results of in vitro test indicated that the ricin was very stable in the serum and the strip could detect ricin at the level of $25 \mathrm{ng} / \mathrm{mL}$ in human serum. This result encouraged us to conduct a further test with the serum samples taken from the rats that were intramuscularly injected with a lethal dose of ricin. Positive test bands were observed for the sera collected at 2 to 24 hour post intoxication. The response time was only $10 \mathrm{~min}$. The result indicates that this method is rapid, sensitive and suitable for the emergency detection of human intoxication with ricin. The results of immunochromatographic strips can be reconfirmed using our previously reported Sandwich ELISA method, which could quantitatively determine ricin in serum samples of poisoned mice [11]. The combination of the strip and the ELISA assay will provide quick qualitative and quantitative detection for ricin poisoning cases. Our further work will focus on developing a ricin enrichment method for serum or plasma samples to increase the assay sensitivity, which is also very important for the ricin assay especially in the cases of sublethal poisoning.

\section{Acknowledgements}

We are grateful to Dr. Liming Guo and Ming Yu for the gift of mouse ascites to prepare Mabs against ricin. This work was supported by a Grants from the National Natural Science Foundation of China (NO. 30772593, 30973562), the National Basic Research Program of China (NO. 2010CB933904).

\section{References}

1. Audi J, Belson M, Patel M, Schier J, Osterloh J. Ricin poisoning: a comprehensive review. J. Am. Med. Assoc.2005; 294(18):2342-2351 doi:10.1001/jama.294.18.2342

2. Dayan-Kenigsberg J, Bertocchi A, Garber EAE. Rapid detection of ricin in cosmetics and elimination of artifacts associated with wheat lectin. J. Immunol. Methods. 2008; 336(2):251-254. doi:10.1016/j.jim.2008.05.007

3. Dill K, Montgomery DD, Ghindilis AL, Schwarzkopf KR, Ragsdale SR, Oleinikov AV. Immunoassays based on electrochemical detection using microelectrode arrays. Biosens. Bioelectron. 2004; 20 (4):736-742.doi:10.1016/j.bios.2004.06.049

4. Feltis BN, Sexton BA, Glenn FL, Best MJ, Wilkins M, Davis TJ A hand-held surface plasmon resonance biosensor for the detection of ricin and other biological agents. Biosens. Bioelectron.2008; 23 (7):1131-1136.doi:10.1016/j.bios.2007.11.005

5. Frens G. Controlled nucleation for the regulation of the particle size in monodisperse gold suspension. Nat Phys Sci.1973; 241(105):2021

6. Garber EAE, Eppley RM, Stack ME, McLaughlin MA, Park DL, Feasibility of immunodiagnostic devices for the detection of ricin, amanitin and T-2 toxin in food. J. Food. Prot. 2005; 68 (6):12941301.

7. Girbés T, Ferreras JM, Arias FJ, Stirpe F. Description, distribution, activity, and phylogenetic relationship of ribosome-inactiviating proteins in plants, fungi, and bacteria. Mini. Rev. Med. Chem. 2004; $4(5): 461-476$

8. Leith AG, Griffiths GD, Green MA, Quantification of ricin toxin using a highly sensitive avidin/biotin enzymelinked immunosorbent assay. J. Forensic Sci. Soc. 1988; 28 (4):227-236.doi:10.1016/ S0015-7368(88)72840-6

9. Ler SG, Lee FK, Gopalakrishnakone P. Trends in detection of warfare agents. Detection methods for ricin, staphylococcal enterotoxin B and T-2 toxin. J. Chromatogr. A. 2006; 1133 (1-2):112.doi:10.1016/j.chroma.2006.08.078

10. Lubelli C, Chatgilialoglu A, Bolognesi A, Strocchi P, Colombatti M, Stirpe F. Detection of ricin and other ribosome-inactivating proteins by an immuno-polymerase chain reaction assay. Anal. Biochem. 2006; 355 (1):102-109.doi:10.1016/j.ab.2006.05.003

11. Men JSH, Lang LW, Wang CHY, Wu JH, Zhao Y, Jia PY, Wei WQ, Wang YX, Detection of residual toxin in tissues of ricin poisoned mice by Sandwich ELISA and immunoprecipitation. Anal. Biochem. 2010; 401(2):211-216doi:10.1016/j.ab.2010.02.033

12. Olsnes $\mathrm{S}$. The history of ricin, abrin and related toxins Toxicon. 2004 ; 44 (4):361-370.doi:10.1016/j.toxicon.2004.05.003

13. Olsnes S, Kozlov JV. Ricin. Toxicon. 2001; 39 (11):1723-1728 doi:10.1016/S0041-0101(01)00158-1

14.Papaloucas M, Papaloucas C, Stergioulas A. Stergioulas. Ricin and Assassination of Georgi Markov. Pakistan. J. Biol. Sci. 2008; 11 (19):2370-2371

15. Shankar K, Zeng KF, Ruan C, Grimes CA. Quantification of ricin concentrations in aqueous media. Sensor. Actuat. B-Chem. 2005; 107 (2):640-648.

16. Shyn RH, Shyu HF, Liu HW, Tang SS. Colloidal gold-based immunochromatographic assay for detection of ricin. Toxicon. 2002; 40 (3):255-285.doi:10.1016/S0041-0101(01)00193-3

17. Stirpe F. Ribosme-inactivating proteins. Toxicon. 200; 44 (4):371383.doi:10.1016/j.toxicon.2004.05.004 
http://nanobe.org

18. Sun XL, Zhao XL, Tang Jian. Optimization of preparation technique of monodispersion colloidal gold. Immunological Journal. 2004; 20 (2), 151-154

19. Tran H, Leong C, Loke WK, Dogovski C. Surface plasmon resonance detection of ricin and $\mathrm{h}$ orticultural ricinvariants in environmental samples. Toxicon. 2008; 52 (4):582-588.doi:10.1016/ j.toxicon.2008.07.008
Copyright:(c) $2011 \mathrm{~J}$. Wu, et al. This is an openaccess article distributed under the terms of the Creative Commons Attribution License, which permits unrestricted use, distribution, and reproduction in any medium, provided the original author and source are credited. 